\title{
"El puente" de Carlos Salazar Herrera: La línea entre el ser (civilización) y el no ser (naturaleza)
}

\author{
Esteban Orias Sarmiento \\ Ministerio de Educación Pública \\ sarniento80@gmail.com \\ https://orcid.org/0000-0002-7321-5956
}

María Patricia Quesada Villalobos Universidad de Costa Rica, Costa Rica. mpquesad@gmail.com https://orcid.org/0000-0001-8014-8790

Recibido: 25 de abril 2018

Aceptado: 23 de julio 2018

\section{Resumen:}

El cuento titulado "El puente" del escritor costarricense Carlos Salazar Herrera muestra la dicotomía planteada por Sarmiento (1845) entre civilización y barbarie, donde el espacio natural se analoga con la barbarie y está representado por la Chela (personaje principal) y sus costumbres. Por otra parte, la civilización se relaciona con valores citadinos, aspecto que simboliza Marcial, personaje que encarna a la sociedad patriarcal, así como el mito del blanqueamiento.

En el proyecto de blanqueamiento "vallecentralino" la invisibilización del mundo indígena era un requisito insoslayable, ya que no encajaba en el modelo civilizador liberal. La otra opción de los grupos subalternizados era huir a los campos agrestes, lejos de las falanges del colonizador. Por ende, la disyuntiva era asimilarse o "desaparecer".

No obstante, en el relato la Chela sufre una cuádruple opresión, pues ella forma parte de un grupo étnico inferiorizado por su cultura, también se le señala por el color de la piel, por ser huérfana y mujer. En este sentido, la Chela, además de encarnar el mito fundacional costarricense, es símbolo de la patria mancillada, burlada y entregada a los brazos del conquistador, personificado por Marcial, quien, a todas luces, alude a lo castrense y a lo belicoso.

Además, interesa recalcar que el puente, cuyo sonido se asemeja al de una

\section{(c) (i) (9) (2)}

La Revista Estudios es editada por la Universidad de Costa Rica y se distribuye bajo una Licencia Creative Commons Atribución-NoComercial-CompartirIgual 3.0 Costa Rica. Para más información envíe un mensaje a 
ISSN 1659-3316

Orias Sarmiento Esteban

Quesada Villalobos María Patricia

Especial: Naturaleza amena y naturaleza agreste en las letras hispánicas marimba, es también el tránsito entre el espacio salvaje y natural, es decir, entre la ruralidad y el espacio civilizado, o entre el pueblo y la ciudad. Adicionalmente, en este artículo se busca explicar cómo el puente constituye la línea del "ser y no ser", aspecto que desarrolla Fanon (1952) y que es posteriormente problematizado por Grossfoguel.

Palabras clave: Literatura costarricense, "El puente", Carlos Salazar Herrera, mito del blanqueamiento, decolonialidad, civilización y barbarie.

\title{
"El puente" by Carlos Salazar Herrera: The line between being (civilization) and non-being (nature)
}

\begin{abstract}
:
The story entitled "El puente" by the Costa Rican writer Carlos Salazar Herrera shows the dichotomy posed by Sarmiento (1845) between civilization and barbarism, where the natural space is analogous to barbarism and is represented by the Chela (main character) and its customs. On the other hand, civilization is related to city values, aspect that Marcial symbolizes, character that embodies the patriarchal society, as well as the myth of whitening. In the whitening project "Vallecentralino", the invisibility of the indigenous world was an unavoidable requirement, since it did not fit into the liberal civilizing model. The other option of the subalternized groups was to flee to the wild fields, far from the phalanges of the colonizer. Therefore, the dilemma was to assimilate or "disappear." However, in the story the Chela suffers a fourfold oppression, since she is part of an ethnic group inferiorized by her culture, she is also indicated by the color of her skin, because she is an orphan and a woman. In this sense, the Chela, besides embodying the Costa Rican founding myth, is a symbol of the tainted country, mocked and surrendered to the arms of the conqueror, personified by Marcial, who, by all accounts, alludes to the military and the bellicose. In addition, it is interesting to emphasize that the bridge, whose sound resembles that of a marimba, is also the transition between the wild and natural space, that is, between rurality and civilized space, or between the town and the city. Additionally, this article seeks to explain how the bridge constitutes the line of "being and not being", an aspect developed by Fanon (1952) and later problematized by Grossfoguel.
\end{abstract}

Keywords: Costa Rican literature, "El puente", Carlos Salazar Herrera, myth of bleaching, decoloniality, civilization and barbarism.

\section{(c) (i) (-)}

La Revista Estudios es editada por la Universidad de Costa Rica y se distribuye bajo una Licencia Creative Commons Atribución-NoComercial-CompartirIgual 3.0 Costa Rica. Para más información envíe un mensaje a revistaestudios.eeg@ucr.ac.cr. 
Cleto González Víquez (1908)

\section{INTRODUCCIÓN}

Tal como reseña Mondol (2015) existen tres representaciones que contribuyen al surgimiento de la identidad nacional costarricense: la familia patriarcal, la imagen del labriego sencillo y la blancura étnica. Esta triada de alguna manera viene a compensar la falta de lo que Sommer (2004) denomina como ficciones fundacionales, al estilo de la Malinche en México o Santa en la era posrevolucionaria priista (Palou, 2014). Es decir, se construyen una serie de metáforas estratégicas (Jiménez, 2002) para procurar legitimar un imaginario que encaje en las pretensiones modernizantes de la "Generación del Olimpo" a falta de un mito fundante vigoroso.

Interesa destacar el tema de la supuesta homogeneidad étnica, pero utilizando la teoría de Fanon y vista desde la perspectiva de Grossfoguel y la corriente del giro decolonial, pues esto permitirá ampliar la visión del racismo tradicional con el cual se ha interpretado la construcción del nacionalismo étnico metafísico, según Jiménez (2002). Esto, a su vez, contribuye a señalar las continuidades que existen en este discurso en la literatura costarricense, específicamente, en el cuento "El puente", escrito por Carlos Salazar Herrera y contenido en el libro Cuentos de Angustias y paisajes, publicado en 1947 y los discursos eugenésicos decimonónicos costarricenses.

\section{(c) (i) (9) (2)}

La Revista Estudios es editada por la Universidad de Costa Rica y se distribuye bajo una Licencia Creative Commons Atribución-NoComercial-CompartirIgual 3.0 Costa Rica. Para más información envíe un mensaje a 
Especial: Naturaleza amena y naturaleza agreste en las letras hispánicas

Se parte de la hipótesis de que en el relato mencionado se reproduce la dicotomía entre civilización y barbarie de Sarmiento, estableciendo dualidades como campo-ciudad, urbanita-campesino, naturaleza-modernidad, inocenciadecadencia y blanquitud-mestizaje, entre otros.

\section{EL CONTEXTO SOCIO-HISTÓRICO DE LA OBRA}

De acuerdo con Salazar (2003), el proyecto de la modernidad se inaugura con el golpe de Estado perpetrado por el general Tomás Guardia (1870) y finalizó

con la llegada al poder del licenciado Alfredo González Flores, primer gobernante reformista de Costa Rica. Fue una época de estabilidad política, pero de gran agitación debido a la forma dictatorial o autoritaria que utilizaron algunos gobernantes para mantenerse en el poder. (p.21)

Este autor destaca la importancia de los cambios acaecidos en casi cinco décadas. Se inicia con una ruptura del orden constitucional mediante la instauración de un gobierno de facto, el cual basa su dominio en el autoritarismo, hasta transitar a gobiernos inspirados en la democracia liberal que se valieron de mecanismos ideológicos, en lugar de la fuerza del aparato castrense. En suma, se pasa de un liberalismo autoritario al liberalismo democrático. (Salazar, 2003).

Posteriormente, Guardia logra apaciguar las luchas internas de los grupos oligárquicos y con esto crea la estabilidad política para iniciar las reformas liberales y su consiguiente progreso material.

Aparejado al desarrollo de la infraestructura nacional, aparece la reforma educativa y constitucional. Con el fin de completar este proyecto material y científico pone en marcha la maquinaria estatal, en procura de

\section{(c) (i) (-)}

La Revista Estudios es editada por la Universidad de Costa Rica y se distribuye bajo una Licencia Creative Commons Atribución-NoComercial-CompartirIgual 3.0 Costa Rica. Para más información envíe un mensaje a 
(...) la construcción de la idea liberal de nación y su implantación en la sociedad costarricense durante el periodo de 1870-1914. La nación se inventa entonces bajo la hegemonía de la llamada oligarquía cafetalera. Las marcas de identidad son la homogeneidad racial de un país blanco, la distribución equitativa de la tierra, la existencia de más maestros que soldados, la ideología del progreso y, en consecuencia, la asunción de la experiencia colonial hispánica como una época oscura. (Jiménez, 2002, p.86)

En este sentido, la consolidación de la identidad nacional está relacionada con el desarrollo de conflictos de diversa índole, ya que el periodo de 1914 a 1948 se caracteriza por una gran inestabilidad política y socio-económica. Tal como se reseñó en las líneas anteriores, 1914 marca un hito en la historia costarricense, pues se considera que con la crisis del Estado Liberal se debe intervenir la economía, situación que inicia en el gobierno de Flores. Al respecto Aguilar (2009), afirma que:

La crisis económica que generó la Primera Guerra Mundial en Costa Rica, debido a la disminución de las importaciones, el aumento de la deuda interna y externa del Estado, la inflación monetaria y la contracción de los ingresos fiscales, puso al descubierto problemas sociales originados desde mucho tiempo atrás. (p.5)

Esta problemática, aunada al golpe de Estado al gobierno de Flores, por parte de los Tinoco, conlleva a la caída del Estado Liberal y el ingreso a un proceso de inestabilidad política que culminaría con la Guerra Civil de 1948.

De acuerdo con Samper (1979) y Botey y Cisneros (1984), citados por Aguilar (2009), la década de los treintas fue testigo de un acelerado proceso de 
Especial: Naturaleza amena y naturaleza agreste en las letras hispánicas proletarización de obreros y campesinos, debido al aumento del desempleo y la pauperización, contexto que se agrava con la problemática fiscal y comercial que vivía el país, como consecuencia de la reducción de los precios del café y el banano, además de la consiguiente contracción de las importaciones. Entre los aspectos que caracterizan esta década están los siguientes:

- Irrupción de huelgas en las zonas centrales del país por parte de obreros del café, zapateros, panaderos, sastres y litógrafos. No obstante, en las zonas periféricas es emblemática también la huelga bananera de 1934.

- En este contexto, y en medio la convulsión social que se vive, se funda en 1931 el Partido Comunista.

- Falta de vivienda y un sistema de salud que sufre serios problemas estructurales.

Posteriormente, el estallido de la Segunda Guerra Mundial (1939-1945) vino a incrementar el sentimiento de inestabilidad generado por la crisis del Estado liberal.

A partir de la década de los años treinta, Salazar escribe los cuentos que serían publicados en 1947 bajo el nombre de Cuentos de Angustias y Paisajes. Por tanto, la corriente de pensamiento del cuentista se debe vincular con este convulso contexto, al respecto Bolaños y González (2010) señalan que

(...) no deja de llamar la atención si se tiene en cuenta que los cuentos de este autor, aun y cuando pertenecen al canon literario nacional, no constituyen un ejemplo típico de la "narrativa social", la cual se encuentra ligada sobre todo, con la novela de la llamada "generación del 40". Su obra, más bien, se asocia con preocupaciones de carácter psicológico y estético. (p.45)

En este sentido, Salazar puntualiza, en su proyecto literario y desde el título mismo de la obra, en elementos asociados a aspectos psicológicos y estéticos,

La Revista Estudios es editada por la Universidad de Costa Rica y se distribuye bajo una Licencia Creative Commons Atribución-NoComercial-Compartirlgual 3.0 Costa Rica. Para más información envíe un mensaje a 
Especial: Naturaleza amena y naturaleza agreste en las letras hispánicas situación que se evidencia tanto en el discurso escrito como en los grabados que acompañan a cada texto, donde se enfatiza la angustia y la soledad de los personajes, así como en el trabajo artístico de la obra.

\section{LA ZONA DEL SER Y NO SER}

Para lograr comprender el cuento "El puente" desde la perspectiva teórica que propone esta comunicación, es necesario analizar la teoría de Fanon (2010) y los aportes de Bounaventura (2010), desde la teoría del giro decolonial de Grossfoguel (2012).

Definir el concepto de racismo, desde este enfoque, es clave para comprender los múltiples marcadores raciales que confluyen en el cuento analizado. Según Grossfoguel (2011):

Para Fanon, el racismo es una jerarquía global de superioridad e inferiodad sobre la línea de lo humano que ha sido políticamente producida y reproducida como estructura de dominación durante siglos por el sistema imperialista / occidentalocéntrico / cristianocéntrico / capitalista / patriarcal / moderno / colonial» (Grosfoguel, 201, p.93)

Como puede inferirse, el vocablo racismo se "marca" por parámetros relacionados con el color de la piel, la etnia, la lengua, la cultura o la religión de un grupo de personas. El más común es el color de la piel, sin embargo, el autor reseña casos, como el irlandés, donde el color de la piel no podía utilizarse como un marcador de racismo, ya que los irlandeses son más blancos que los ingleses. Por ende, se estableció una dicotomía de superioridad/inferioridad por la religión: ingleses-superiores-católicos ante los irlandeses-inferiores-protestantes. A todas luces esto era un conflicto colonial-racial, disfrazado de conflicto religioso.

\section{(c) (i) (-)}

La Revista Estudios es editada por la Universidad de Costa Rica y se distribuye bajo una Licencia Creative Commons Atribución-NoComercial-CompartirIgual 3.0 Costa Rica. Para más información envíe un mensaje a 
Especial: Naturaleza amena y naturaleza agreste en las letras hispánicas

Esta visión, que considera a unos superiores a otros, es lo que Fanon (2010), citado por Grosfoguel (2012), describe como las zonas de ser y no ser:

En la zona del ser, los sujetos, por ser racializados como seres superiores, no viven opresión racial, sino privilegio racial [...] esto tiene implicaciones fundamentales en cómo se vive la opresión de clase, sexualidad y género. En la zona del no-ser, debido a que los sujetos son racializados como inferiores, ellos viven opresión racial en lugar de privilegio racial. Por tanto, la opresión de clase, sexualidad y género que se vive en la zona del no-ser es cualitativamente distinta a como estas opresiones se viven en la zona del ser. (p.94).

En este punto cabe cuestionarse ¿dónde está el origen de esta construcción racista- dicotómica entre lo superior/inferior, basado en marcadores referenciados?, aspecto al que Grosfoguel (2012) responde en los siguientes términos:

Existía ya a fines del siglo XV en la península ibérica el discurso acerca de la «pureza de sangre». Este discurso era una forma de proto-racismo movilizado contra las poblaciones musulmanas y judías durante la conquista colonial por parte de la monarquía católica para destruir el poder político musulmán en península ibérica, territorio conocido como Al-Ándalus. La práctica de limpieza étnica del territorio conllevó un genocidio contra las poblaciones musulmanas y judías. (p.87)

Sin embargo, será el choque entre los pueblos originarios de América y el "mundo español" el que configura la racialización del "otro", siendo el marcador religioso la primera forma de racismo-moderno, ya que los invasores catalogaron a los indígenas como "pueblos sin religión". "Pero no tener religión en el imaginario cristiano de la época era equivalente a no tener alma, es decir, ser expulsado del "reino de lo humano" hacia el "reino animal". (Grosfoguel, 2012, p.89).

\section{(c) (i) (2) (2)}

La Revista Estudios es editada por la Universidad de Costa Rica y se distribuye bajo una Licencia Creative Commons Atribución-NoComercial-CompartirIgual 3.0 Costa Rica. Para más información envíe un mensaje a 
Especial: Naturaleza amena y naturaleza agreste en las letras hispánicas

Durante la primera mitad del siglo XVI, la controversia entre Sepúlveda y De las Casas giró en torno a si los indígenas tenían alma o no, pues si no tenían eran animales-no humanos en la línea del no-ser, si tenían debían ser cristianizados, formaban parte de la línea del ser, eran humanos. De las Casas, con la posición culturalista, afirmaba que los autóctonos tenían alma, pero estaban en un estado primitivo, en la barbarie y, por lo tanto, correspondía cristianizarlos. Ginés Sepúlveda, por su parte, creía que no tenían alma y que eran sujetos de ser esclavos -racismo-teológico-.

Posteriormente, Grosfoguel (2012) opina que con el advenimiento de la razón ilustrada, el discurso teológico de Sepúlveda deviene en racismo biológico pueblos sin genes humanos- y el discurso de Bartolomé en discurso racista culturalista- pueblos primitivos sin civilizar-. Así, a partir del siglo XVI, todo pueblo con un Dios "diferente" no tenía alma, era un animal y su única salvación era cristianizarlo. Esta fórmula en el siglo XIX se traduce en que toda comunidad, sin los principios de la llustración, era bárbara y, en otros casos, razas inferiores o ambas posiciones imbricadas en un discurso biológico-culturalista. Los pueblos africanos entraron en la categoría de no humanos y los indígenas en subhumanos.

En las siguientes líneas se procura integrar los aspectos teóricos discutidos anteriormente al análisis literario del cuento denominado "El Puente" de Carlos Salazar Herrera.

\section{LECTURA DECOLONIAL DEL CUENTO "LA SEQUÍA”}

Como se afirmó en líneas anteriores, Bolaños (2010) asegura que Salazar no encaja con la narrativa del "realismo social" de los años cuarenta, más bien su preocupación se orienta a la introspección psicológica y a lo estético.

\section{(c) (i) (9) (2)}

La Revista Estudios es editada por la Universidad de Costa Rica y se distribuye bajo una Licencia Creative Commons Atribución-NoComercial-CompartirIgual 3.0 Costa Rica. Para más información envíe un mensaje a 
Especial: Naturaleza amena y naturaleza agreste en las letras hispánicas

Sin embargo, esta deslocalización y/o desterritorialización es un recurso valioso que permite superar dicotomías rígidas como campo/ciudad, naturaleza/urbe, civilización/barbarie, y otros, pues no en pocas ocasiones estas dicotomías se imbrican conformando espacios heterogéneos atravesados por la contradicción. En este sentido, según Grosfoguel (2012)

La zona del ser y no-ser no es un lugar geográfico específico, sino una posición en las relaciones raciales de poder que ocurren a escala global entre centros y periferias, pero que también ocurren a escala nacional y local contra diversos grupos racialmente inferiorizados. Existe un colonialismo interno tanto en el centro como en la periferia. (p.95)

Partiendo de estos postulados, Marcial Reyes representa al colonialismo interno, pues simboliza al conquistador/violador, el terrateniente, el patriarca, el jinete, ya que personifica la violencia y el aparato castrense, aspecto que se visualiza en el siguiente fragmento:

El caso de la pobre Chela era un asunto vulgar; y para que fuera más común, cierta mañana de domingo, Marcial Reyes salía de la iglesia y cogida de su brazo, con el velo y azahares de naranjo, la linda Rosario Víquez. (Salazar, p.6)

Es decir, Marcial se encuentra en la zona del ser como un colonizador con privilegios raciales, de esta manera, encarna también el mito del blanco vallecentralino, su mismo nombre hace referencia a este aspecto.

Sin embargo, en el marco de las relaciones internacionales capitalistas sexistas, patriarcales y racistas, Marcial es "un campesino, un mestizo y un bárbaro”. En su lengua expresa su ruralidad: “- ¡Cuidao vas a contarle a naide nada! —dijo él (Salazar, p.6). En suma, se presenta como la antítesis de lo 
Especial: Naturaleza amena y naturaleza agreste en las letras hispánicas urbano, lo civilizado y lo ilustrado.

Pero, ¿cómo el bárbaro adquiere estos privilegios raciales, siendo un sujeto que está por debajo de la línea abisal en la zona del no ser, al respecto Grosfoguel (s.f.) indica que

esto tiene que ver con el divide y vencerás, los grupos hegemónicos ejercen como parte de la colonialidad una división entre los grupos inferiorizados haciéndole algunos creer que están más cerca de lo blanco que de lo indígena, entonces "estos" a pesar de que no son vistos como humanos por este grupo les hacen creer que están más cerca de "aquí" que "de acá" y crean una división que son inferiorizados en la sociedad [...] la categoría de sub-humano y no humano son importantes aquí, porque ambas son categorías de inferiorización debajo de la línea de lo humano, pero establece una jerarquía ahí entre unos y otros para ponerlos a pelear entre ellos (Grosfoguel (2012)

Desde esta perspectiva, Marcial Reyes aparece como el hombre/patriarca que representa los valores de un citadino inteligente, aprovechado, mujeriego y buscador de aventuras, que no tiene ningún miramiento para engañar a una campechana ingenua que aún cree que Reyes la puede amar, de ahí que su apellido aluda a la monarquía: "La muchacha, entonces, se asomaba por la ventana de su casa, y tan pronto reconocía a Marcial Reyes, echaba a correr por el cercado hacia la vuelta del camino, y allí esperaba al jinete " (Salazar, p.6).

Los privilegios raciales del sub-humano en la zona del no ser no son nada despreciables. Así lo quiere el yo imperial para mantener su dominio del sistema mundo. Desde su primera aparición Marcial ostenta el símbolo del conquistador: el caballo.1, razón por la cual no es de extrañar que aparezca montado en su bestia. El narrador describe la escena de su advenimiento cuando afirma:"el trote de un caballo hacía sonar la tablazón... el potro sabía que era cosa de detenerse y, como si quisiera lucirse en un desplante, se empinaba en dos patas y adornaba la cabriola con un relincho". (Salazar, p.6).

\section{(c) (i) (2)}

La Revista Estudios es editada por la Universidad de Costa Rica y se distribuye bajo una Licencia Creative Commons Atribución-NoComercial-CompartirIgual 3.0 Costa Rica. Para más información envíe un mensaje a 
Especial: Naturaleza amena y naturaleza agreste en las letras hispánicas

Esta escena describe en una pieza al "conquistador/violador", pues es sabido que los jinetes, en el momento de iniciar la conquista del enemigo en la guerra, hacen que sus caballos se posicionen en dos patas como símbolo de arrogancia y dominación. De esta manera, el jinete, al mostrar su bestia capada, indica que él ha absorbido la virilidad del animal y, por ende, sus atributos sexuales. Esto es una especie de proyección sexual que indica a la mujer que ella será el próximo trofeo, pues el conquistador no conquista, sino que viola y arrebata, ya sea por la fuerza o por la mentira. Si es capaz de montar un potro brioso, cómo no dominar una potranca de poca monta, se figura el "montador": "Ola iba como ceñida a unas riendas trenzadas con palabras..."(Salazar, p.6)

Así Salazar aprovecha el ambiente natural para introducir elementos de dominación colonial-patriarcal y racista. Racista en el sentido de que Marcial se asume como un "blanco honorario", cerca de la línea del ser, mestizo que es invisibilizado por la "Generación del Olimpo", un acto de presdigitación gracias a las metáforas estratégicas que habla Jiménez (2002) o las representaciones que reseña Mondol (2015). Si bien en este cuento el personaje masculino no es descrito en sus rasgos físicos, en el relato "El Mestizo2, Salazar nos presenta un hombre donde es claro que no posee bienes, es inculto, agresivo y pendenciero. Este proceso de des-mestización lo describe Jiménez (2002) cuando afirma que

Al empezar el siglo XIX, aparte de una pequeña capa de españoles, el resto de la población costarricense era mestiza. Sin embargo, a mediados de ese siglo, y sin que hasta ahora se haya explicado cómo sucedió, la narrativa nacionalista borra la herencia étnica africana y las distinciones de identidades étnicas de carácter oficial. No se habla más de mulatos, los pardos, los esclavos negros o los diversos grupos indígenas. Asimismo, la población mestiza y española pasa a ser designada oficialmente y sin más "blanca". (191-192)

Es claro que Marcial es "blanco", al menos posee una mejor posición 
Especial: Naturaleza amena y naturaleza agreste en las letras hispánicas

jerárquica en las relaciones raciales, pues tiene privilegios de raza. La existencia del mestizo es imposible, ya que él es un híbrido entre lo blanco y lo indígena. Aquí se establece un ensamblaje imposible de digerir para el liberalismoeugenésico. La dicotomía del yo imperial y el otro bárbaro pueden describirse así: el salvaje indígena/bárbaro iletrado/sin genes ante la raza aria, letrada y portadora de la civilización. Es decir, el mestizo está atrapado entre dos mundos y en ninguno encaja, por eso los liberales recurren a relatos donde los discursos racistas/culturalistas/biológicos y patriarcales están presentes:

Al provenir supuestamente de varones españoles y mujeres indígenas, y dada una serie de presunciones sexistas, prima la sangre blanca de aquellos hombres heroicos. Es decir, "el costarricense" es asumido como el producto de un mestizaje con preponderancia blanca. Los genes de los conquistadores parecen tener un poder mítico para lograr mantener, aún en procesos de mestizaje con poblaciones numéricamente superiores, su supuesta blancura. (Jiménez, 2002, p.193).

\section{LA CHELA: UN NO-HUMANO CON OPRESIÓN RACIAL}

En el colonialismo interno "La Chela" funge el papel de un no-humano, no tiene privilegios raciales, al contrario, vive la opresión racial. Dadas las referencias, es imposible saber si la Chela es mestiza o indígena, pero eso carece de importancia, pues de todas formas es tratada como si no fuera blanca, tampoco mestiza, sino como indígena. La Chela es caracterizada como un ser sin alma, como un animal, como un no-humano:

- Hace tiempos —le dijo- que no vas a confesarte, hija mía. La muchacha bajó la cabeza.

El párroco insistió: — ¿Por qué no te vas a confesar?

La Revista Estudios es editada por la Universidad de Costa Rica y se distribuye bajo una Licencia Creative Commons Atribución-NoComercial-CompartirIgual 3.0 Costa Rica. Para más información envíe un mensaje a 
Especial: Naturaleza amena y naturaleza agreste en las letras hispánicas La Chela se encogió de hombros y sin levantar la cabeza, miraba el entablado sonoro del puente. (Salazar, p.7)

Por otra parte, la Chela es una mujer huérfana, sufre la ausencia de una figura patriarcal fuerte que proteja su dignidad, por esta razón el narrador afirma que "La Chela era huérfana y por eso, vivía arrimada a su padrino" (Salazar,p.6), nótese el acento que la frase le pone a la palabra "arrimada", como alguien dependiente económicamente de otra persona y que termina siendo una responsabilidad incómoda que no se desea cargar. En este sentido, la Chela se siente poco valorada, como un peso y un estorbo, porque además es una mujer campesina, sin educación ilustrada, pobre y que ha perdido sus privilegios raciales, así aunque ella fuera blanca o mestiza, es expedida a la línea del no-ser.

¿Qué tiene Rosario Víquez que no tiene la Chela? La respuesta es evidente "respetabilidad" y poder adquisitivo. Una vez más Grosfoguel (2012) alude a este asunto cuando explica que:

A pesar de que el hombre heterosexual no-Occidental es un oprimido en la zona del no-ser en relación con la zona del ser, la situación social es todavía peor para una mujer o un gay/lesbiana en la zona del no-ser. El problema es que la mujer no-occidental y los gays/lesbianas nooccidentales en la zona del no-ser son no solamente oprimidos por los pueblos occidentales que habitan en la zona del ser, sino también por otros sujetos pertenecientes a la zona del no-ser. Esto último implica una doble, triple o cuádruple opresión para los sujetos oprimidos no-occidentales dentro de la zona del no-ser que no se compara con el acceso a los derechos humanos/civiles/laborales, las normas de civilidad, los ingresos/salarios y los discursos emancipatorios reconocidos y vividos por los sujetos occidentales oprimidos dentro de la zona del ser. (p.97)

Esto logra dar cuenta de la situación de la Chela en las zonas marcadas por la línea abisal que habla De Souza (2010), es decir, a pesar de ser mujer como

La Revista Estudios es editada por la Universidad de Costa Rica y se distribuye bajo una Licencia Creative Commons Atribución-NoComercial-CompartirIgual 3.0 Costa Rica. Para más información envíe un mensaje a 
Especial: Naturaleza amena y naturaleza agreste en las letras hispánicas

Rosario Víquez, no es reconocida su humanidad por estar debajo de la línea jerárquica en la zona del no-ser.

En suma, vive opresión por parte de la zona del ser por su color de piel, se evidencia también el abuso del que es víctima en la línea del no-ser por su género y su clase. Es evidente que La Chela no posee el mismo valor simbólico que Rosario Víquez, pues ella tiene apellido y la huérfana carece de él, ni siquiera puede ser nombrada, no existe, es decir, es oprimida al cuádruple.

Se reconoce como opresión al cuádruple porque además de los aspectos señalados, la Chela no tiene religión, esto la termina de caracterizar como una indígena más que como una mestiza o blanca. ¿Cómo se puede sostener este argumento?, se debe recordar que el cura un día se encontró a la Chela sobre el puente de madera y le dijo:

- Hace tiempos -le dijo- que no vas a confesarte, hija mía. La muchacha bajó la cabeza. Él párroco insistió: - ¿Por qué no te vas a confesar? La Chela se encogió de hombros y sin levantar la cabeza, miraba el entablado sonoro del puente. ¡Cómo iba a confesarse, si había jurado... "no contarle a naide nada"! (Salazar, p.7)

Al no confesarse rompe los lazos con la iglesia católica, ya sea por (dis)gusto o por la culpa de sus "pecaminosos actos". Esta ruptura se concreta con la quema del puente: "Una noche tostada de verano, alguien, —nunca se supo quién- le prendió fuego al puente”. (Salazar,p.7), decisión que la despoja de su religión, aspecto que constituye una especie de excomunión a nivel simbólico.

Referirse a los indígenas como sujetos sin religión los saca aparte de la categoría de lo humano. Como la religión es algo universal en los humanos, la falta de la misma no denota la falsedad de la proposición, sino al contrario, el hecho de que hay sujetos que no son del todo humanos en el mundo ( Grosfoguel, 2012, p.89)

\section{(c) (i) (2)}

La Revista Estudios es editada por la Universidad de Costa Rica y se distribuye bajo una Licencia Creative Commons Atribución-NoComercial-CompartirIgual 3.0 Costa Rica. Para más información envíe un mensaje a 
Especial: Naturaleza amena y naturaleza agreste en las letras hispánicas

Esta fórmula del siglo XVI es un remanente colonial que termina por convertirse en un marcador racial para descalificar la humanidad de la Chela. El acto de inferiorización está consumado gracias a que se ha logrado caracterizar a la Chela con rasgos más indígenas que blancos: su sexualidad es desordenada y sucumbe ante sus "deseos más bajos". Esto demuestra su animalidad, su incapacidad de auto-control. Sus impulsos salvajes están más presentes que los procesos de introyección de los valores civilizados, a esto contribuye su falta de educación, además, es huérfana hija del pecado, una condenada de la tierra, según lo anota Fanon,(2010), citado por Grosfoguel, (2012).

Ante esta perspectiva, se presenta en el siguiente cuadro una comparación de dos mujeres, una en línea del no ser-subhumana y otra en la línea del no ser deshumanizada o no-humana.

\section{Cuadro 1}

Comparación entre personajes femeninos

\begin{tabular}{|c|c|}
\hline En la línea del no-ser sub-humanizada & En la línea del no ser deshumanizada \\
\hline Rosario Víquez & La Chela \\
\hline Mujer con privilegios raciales & Mujer con opresión de raza \\
\hline Con apellido & Sin apellido \\
\hline Con familia "legítima" & Huérfana \\
\hline De familia con poder adquisitivo & Pobre \\
\hline Esposa & Amante \\
\hline Casta & "manchada por la lujuria" \\
\hline Fidelidad & Infidelidad \\
\hline Con religión (católica) & Sin religión \\
\hline Civilizada & Salvaje \\
\hline Urbanita & Campesina \\
\hline Bendecida por la iglesia & Ex comulgada \\
\hline Sumisa & Indomable \\
\hline Con genes europeos predominantes & Sin genes europeos, más indígena \\
\hline
\end{tabular}

La Revista Estudios es editada por la Universidad de Costa Rica y se distribuye bajo una Licencia Creative Commons Atribución-NoComercial-CompartirIgual 3.0 Costa Rica. Para más información envíe un mensaje a revistaestudios.eeg@ucr.ac.cr. 
ISSN 1659-3316

Orias Sarmiento Esteban

Quesada Villalobos María Patricia

Especial: Naturaleza amena y naturaleza agreste en las letras hispánicas

Al final, las conductas y valores vinculados a una moral victoriana acercan

más a Rosario Víquez a la línea del ser y, por el contrario, los rasgos descritos acercan a la Chela al mundo indígena. Así, el color de la piel no es el marcador más importante, sino la religión católica y las conductas patriarcales/sexistas que la acompañan y, por supuesto, los rasgos culturales vinculados con la ilustración y los valores victorianos.

De esta manera, la Chela sufre un proceso de des-blanqueamiento o desmestización a nivel simbólico, lo cual está vinculado a la ficción fundacional (Sommer, 2009) de la Costa Rica blanca. Refiriéndose a este proceso Mondol (2015) señala que

Durante el siglo XIX, ese sistema de se convierte en un rasgo fundamental para construir el modelo de identidad nacional. Entonces, en el proceso de invención de la nación costarricense, las élites dominantes retoman el elemento de la blancura como un signo ligado a la moralidad, la democracia, el trabajo, el orden y el progreso. Es decir, todo un conjunto de valores y representaciones oficiales que reprodujeron una visión civilizada y occidental, que al mismo tiempo les permitía borrar todo vestigio o relación con las culturas indígenas y mestiza. $(p, 15)$.

En el próximo apartado se discute la forma en que se vincula el relato estudiado con la ficción fundacional del hombre blanco valle-centralino.

\section{EL ESTADO FALLIDO (MARCIAL) Y LA NACIÓN ULTRAJADA (LA CHELA).}

Se puede afirmar que Marcial Reyes también puede concebirse como símbolo del mito fundacional del costarricense blanco y, al mismo tiempo, como el padre-Estado, un Estado fallido. Igualmente, la Chela se puede equipar con la nación costarricense, como el cuerpo sobre el cual actúa ese Estado.

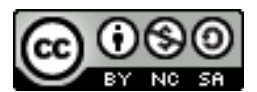

La Revista Estudios es editada por la Universidad de Costa Rica y se distribuye bajo una Licencia Creative Commons Atribución-NoComercial-CompartirIgual 3.0 Costa Rica. Para más información envíe un mensaje a revistaestudios.eeg@ucr.ac.cr. 
Ya se ha señalado que a finales del siglo XIX, el advenimiento del Estado Liberal vino aparejado con la construcción de la identidad nacional. Sin embargo, la Primera Guerra Mundial, y luego la crisis de 1929, hicieron que el Estado de la "Generación del Olimpo" se desvaneciera.

Los "hombres fuertes" de la "Generación del Olimpo" fueron los que asumieron la construcción del Estado Liberal decimonónico, estos a su vez edificaron los cimientos jurídicos, identitarios y pedagógicos para erigir el Estado Nacional costarricense. Esta formación del aparato estatal estuvo acompañada de un discurso que prometía el "orden y el progreso" y para materializar esa visión se avocaron a la construcción de obras tales como: El Teatro Nacional, El Archivo Nacional, El Museo Nacional, entre otros.

En este sentido, Marcial Reyes simboliza al Estado Liberal, tomando en cuenta la decadencia simbólica del mito de "orden y progreso" en la década de los treintas, ya que representa una clase política que recurre al engaño y la mentira para lograr continuar expoliando a la nación. Es evidente que la Chela representa a esa nación que ha sido saqueada, violada y estafada por "los blancos" que se presentan a caballo mostrando su decadente poderío.

Así, la orfandad de la Chela representa a la nación que ha perdido a su padre, el mismo que procuraba, mediante el discurso, hacer creer que la sociedad iba progresando conforme se adoptaran los valores del Estado patriarcalcapitalista, aspecto que puede ser considerado un parricidio ocasionado por el propio sistema económico que le dio vida, contradicciones que le provocan el colapso. Los movimientos sociales de los 30 s vienen a propinar el golpe final que produce su muerte simbólica, de tal manera que la nación, representada en la Chela, queda, al fin, huérfana.

En este sentido, La nación/ Chela es la representación de ese cuerpo que ha sido tomado y ultrajado por los "blancos", del cual también se han burlado. De 
Especial: Naturaleza amena y naturaleza agreste en las letras hispánicas ella han tomado lo que quisieron ofreciendo "oro por cuentas de vidrio" y luego se marcharon dejando su cuerpo estéril (nótese que la Chela no quedó embarazada). Si hubiera procreado, sería profundizar "el error" de continuar mezclándose con los bárbaros del otro lado del puente, es decir, de la línea del no-ser deshumanizada.

Por su parte, Rosario Víquez representa la continuidad de la pureza de la raza. Ella es la representación de lo puro y, por ende, tiene la capacidad de dar vida, es la tierra fértil sobre la cual se cultivarán los frutos del mañana.

Así las cosas, la angustia de la Chela es la incertidumbre que vive una nación en medio del caos, de un Estado débil, corrupto, que toma lo que quiere sin dar nada a cambio y sujeto a las invasiones de los extranjeros, del comunismo o la intervención de los estadounidenses. Estos discursos, de acuerdo con Jiménez (2002) fueron

Elaborados fundamentalmente por dos grupos: Ios intelectuales críticos del orden liberal, y los círculos de obreros y artesanos organizados en torno a ideas anarquistas, socialistas y comunistas. La percepción de la nación amenazada, que es el terreno de disputa ideológica, difiere de la naturaleza de la amenaza. Para unos es el capital extranjero y la expansión de los Estados Unidos. Para otros son las ideas exóticas y radicales.(pp.8687).

En suma, "El desamor en el romance nacional es una respuesta comprensible a una serie de frustraciones económicas y políticas". (Sommer, 2009, p. 334). ¿Acaso la muerte del padre tirano se anuncia como la posibilidad de crear un padre-benefactor, como un proceso de transición hacia otro padre imaginario no-patriarcal, no-déspota? (Palou, 2014) En este paisaje agreste de incertidumbre: ¿cuáles son las opciones para salir de este debacle social?

\section{(C) $(00$}

La Revista Estudios es editada por la Universidad de Costa Rica y se distribuye bajo una Licencia Creative Commons Atribución-NoComercial-CompartirIgual 3.0 Costa Rica. Para más información envíe un mensaje a 


\section{EL PUENTE: LA GEOGRAFÍA DE LA DEGENERACIÓN}

El puente en el texto referido representa dos mundos: uno donde la ruralidad, la naturaleza y la marginalidad están presentes. Ahí viven los "indígenas", los cuales son ingenuos, con instintos sexuales desordenados, analfabetos, pobres y sin un centro de adoración cristiano. Recordemos que el sacerdote (símbolo de la iglesia católica) ni siquiera se atreve a cruzar el puente, pues sabe muy bien que del otro lado es el espacio geográfico donde la degeneración y la lujuria son la marca permanente.

En ese otro lado del puente se ubican los no-humanos. Allá están los hijos producto del pecado, seres inferiores, bastardos. Por consiguiente, el puente representa la línea abisal que marca el mundo del infra-mundo.

A nivel social representa los "Sans Culottes", la plebe que ha sido marcada por la mezcla de sangres, el estrato de la nación que no cumple con los requisitos para ser "blanco". Son a su vez los espacios rurales, alejados de la ciudad y la marca indeleble de civilización que trae consigo.

Por otra parte, al otro lado del puente están los rasgos representativos de los poderosos - la Iglesia Católica y los conquistadores blancos-. Son la clase política que enarbola la bandera del linaje español, sin mezclas y, por tanto, herederos de los colonizadores como Pedro de Alvarado, Pizarro, Hernán Cortés, Pedro Arias Dávila, y muchos otros, que representan la religión y el Dios correcto, la raza aria, el progreso, el orden, las buenas costumbres, la morigeración de sus pasiones sexuales, el recato, los buenos modales, la intelectualidad y todos los valores citadinos que acompañan al yo imperial.

Rosario Víquez será así la mujer blanca, o blanqueada, que merece el amor de Marcial Reyes, pues ella es casta, virginal y de "buena familia". Su nombre, Rosario, es una clara alusión a su estatus de humano, pues tiene religión 
Especial: Naturaleza amena y naturaleza agreste en las letras hispánicas y su apellido (Víquez) recuerda a un viejo político ultra liberal (Cleto González Víquez). Esta es la amalgama de la polis con eros (Sommer, 2009). En definitiva, es la zona del no-ser sub-humanizada, que juega a ser "de la línea del ser", los híper-humanos con privilegios de clase.

Una vez analizados los aspectos que se han anotado, cabe cuestionarse, ¿cuál es la solución que impone Salazar ante esta disyuntiva?, ¿qué significa quemar el puente?, ¿es un acto de ruptura con el mundo occidentalizado o, por el contrario, el aislamiento de los grupos "indigenizados"?, ¿es la marginación ante la imposibilidad de los mestizajes?

La línea continuista se puede interpretar en diversos ámbitos. En primer lugar, es claro que Salazar Herrera retrata dos mundos: uno donde están los grupos que son caracterizados como "no blancos" y los que son "blancos". Esto se convierte en una continuidad, pues se insiste en reproducir el discurso liberal eugenésico basado en el blanqueamiento del mestizo citadino y la "indigenización" de los demás grupos.

En segundo lugar, se muestra una clara dicotomía entre el espacio "bárbaro", ubicado en la superficie rural, el campo y la naturaleza, representado por la Chela, el río y los cuchillitos de poró. Además, también se presenta el espacio "civilizado" situado en la ciudad, representado por Marcial Reyes, su caballo, Rosario Víquez y el sacerdote. Postura que mantiene viva la dicotomía entre civilización/barbarie.

En el cuento "La sequía" de Carlos Salazar Herrera es claro que la Iglesia Católica simboliza el orden moral y espiritual que debe velar porque las almas de la "zona del ser" no se contaminen con los de la "zona del no-ser". Esta tendencia se profundizará con la llegada al poder de los calderonistas en la década siguiente.

Finalmente, ¿la quema del puente representa continuidad o ruptura?. En esta hipótesis del continuismo se considera que Salazar Herrera ve la mezcla 
ISSN 1659-3316

Diciembre 2018

Orias Sarmiento Esteban
Quesada Villalobos María Patricia

Especial: Naturaleza amena y naturaleza agreste en las letras hispánicas

como un imposible. "Lo bueno" del blanco no tiene futuro si se mezcla con "lo malo" del "no blanco". De manera que la quema del puente significa dejar aislado al "indígena" en sus reservas con su geografía de la degeneración y con sus análogos. Es decir, reproducir el proceso de invisibilización realizado por los liberales del siglo XIX.4

Así, el mundo del no-ser deshumanizado desaparece una vez más y se logra proseguir con el mito del hombre blanco. Desde esta perspectiva, Salazar Herrera revitaliza la "solución final decimonónica". La quema del puente es la angustia de la mezcla imposible.

Lo más trágico es que los mismos seres deshumanizados aceptan voluntariamente el ostracismo socio-cultural, económico y político, no cuestionan la inferiorización, más bien aceptan su destino con impavidez.

La Revista Estudios es editada por la Universidad de Costa Rica y se distribuye bajo una Licencia Creative Commons Atribución-NoComercial-CompartirIgual 3.0 Costa Rica. Para más información envíe un mensaje a revistaestudios.eeg@ucr.ac.cr. 


\section{Referencias bibliográficas}

Bolaños, B., y González, G. Espacio rural e identidad nacional en los audiovisuales hechos a partir de la obra literaria de Carlos Salazar Herrera. En revista Comunicación, Vol.19,año 31, N. 2, agosto-diciembre, 2010, p.p.43-51.

Grosfoguel, R. (2012). El concepto de "racismo" en Michel Foucault y Frantz Fanon: ¿teorizar desde la zona del ser o desde la zona del no-ser? Estados Unidos: Tabula rasa.

Grosfoguel, R. (2012, Mayo, 14). "Zona del ser" y "zona del no-ser": Estudios de migración y epistemología. Trabajo presentado en el Máster Internacional de Migraciones Internacionales (MOMI) de la Universidad de Coruña. Coruña, España.

Jiménez, A. (2002). El imposible país de los filósofos. Costa Rica: EUCR.

Mondol, M. (2015). Identidades literarias. Una aproximación sociohistórica a la literatura costarricense. Costa Rica: EUNED

Palou, A. (2014). El fracaso del mestizo. México: ARIEL

Sommer, (2009). Ficciones fundacionales. Las novelas nacionales de América Latina. México: Fondo de Cultura Económica.

\section{(C) $(00$}

La Revista Estudios es editada por la Universidad de Costa Rica y se distribuye bajo una Licencia Creative Commons Atribución-NoComercial-CompartirIgual 3.0 Costa Rica. Para más información envíe un mensaje a 